\title{
Janusz Balicki
}

\section{Christian-Muslim co-operation}

\section{in a secular age. Areas of collaboration}

\section{Współpraca chrześcijańsko-muzułmańska w erze sekularnej. Obszary kooperacji}

Współczesna Europa, podlegając silnej sekularyzacji, zatraciła wiele ze swych źródłowych, chrześcijańskich wartości. W ostatnich latach, wskutek wojny w Syrii i działalności ISIL, istotnie przy tym wzrosła w niej liczba muzułmanów. Wydaje się zatem interesujące czy pojawienie się muzułmanów z mocnymi religijnymi wartościami tworzy możliwość dla chrześcijan do współpracy i wzmocnienia wierzeń. Celem artykułu jest identyfikacja możliwych obszarów kooperacji chrześcijańsko-muzułmańskiej w świeckiej Europie i określenie podstawowych warunków, które mogą uczynić tę współpracę możliwą. Odpowiedź na to pytanie przynosi analiza wierzeń muzułmanów i ich stosunku do małżeństwa i ochrony życia; analiza współpracy chrześcijańsko-muzułmańskiej na forum ONZ, państw, a zwłaszcza Wielkiej Brytanii, i NGO’s.

Słowa kluczowe: chrześcijanie, muzułmanie, kooperacja, ONZ, Wielka Brytania, Europa

In recent years, the Muslim population in Europe has increased in a significant way due to the large inflow of immigrants from Muslim countries caused by the war in Syria and the activity of the Islamic State. In the long history of Christian-Muslim relations, these two religions, with their respective political powers, were involved in many conflicts. Europe has become very secular and lost some of her Christian values. It would be interesting to see if the influx of Muslims with strong religious values creates an opportunity for Christians to co-operate in some areas and to strengthen common beliefs. The aim of this article is to identify possible areas of co-operation between Christians and Muslims in the secular Europe and the basic conditions that must be met to make this co-operation possible. The answer is given through the analysis of the following issues: main disputes between Christian churches and liberal legislation regarding marriage, family values and the protection of human life; analysis of the world wide Muslim beliefs and attitude to family and protection of life; analysis of the co-operation of Christians and Muslims at the UN, in different States or NGOs in the area of legislation protection as well as the co-operation of Christians and Muslims in Great Britain at the basic level. At the end of the article, the main results and conclusions are presented.

Keywords: Christians, Muslims, cooperation, UN, Great Britain, Europe 
During the last 60-70 years Western Europe has changed from being a continent of emigration to a continent of immigration. It is one of the most attractive places for immigrants. They come from different parts of the world. Western Europe is a highly developed part of the world and in terms of demography experiences low fertility and an ageing society, which creates a need for immigrants. According to the theory of the Second Demographic Transition, the fertility rate below replacement level was caused by deep cultural changes: secularization, individualism, and the questioning of religion and moral authorities. This has created a situation where the immigrants' system of values and the current system of values in Europe are often different.

In recent years Europe has been experiencing a big inflow of immigrants from Muslim countries which has caused a significant increase in Muslims especially in Germany with more than one million of them. Regardless of the war in Syria the inflow from North Africa will continue. The aim of this article is to identify possible areas of co-operation between Christians and Muslims in the secular world and the basic conditions that must be met to make this co-operation possible.

The answer is given through the analysis of the following issues: main disputes between Christian churches and liberal legislation regarding marriage, family values and the protection of human life; analysis of the world wide Muslim beliefs and attitude to family and protection of life; analysis of the co-operation of Christians and Muslims at the UN, in different States or NGO's in the area of legislation protections, as well as the cooperation of Christians and Muslims in Great Britain at the basic level. At the end of the article, the main results and conclusions are presented.

\section{PROCESS OF THE CHANGING OF VALUES IN EUROPE}

\subsection{Changing of values in Europe during the Second Demographic Transition}

In his model of the Second Democraphic Transition, the Dutch demographer Dirk van de Kaa describes the demographic situation in Europe in the following way:

- substantial decline in period fertility;

- substantial decline in the total first marriage rate associated with an increase in mean age at first marriage;

- strong increase in divorce and in the dissolution of unions;

- strong increase in cohabitation, even in countries where this was not a traditional practice;

- strong increase in the proportion of extra-marital births;

- catalytic shift in contraceptive behaviour with modern means replacing traditional methods [van de Kaa 2002]. 
Besides according to him there is a shift from uniform families and households to pluralistic ones, a shift from identical patterns to diversified ones, from families consisting of married parents with children to those of different types and forms. The number of one-person households increases, as well as the number of same sex (or different sex) consensual unions and a number of one-parent households (male or female) with children [van de Kaa 2002]. This explanation of the demographic process in Europe shows clearly its cultural and moral situation.

\subsection{Values of European Fieldwork Report 2012}

The changes in the society mentioned in the Second Demographic Transition are shown in the research of Values of Europeans Fieldwork Report 2012 (Table 1:1). Europeans were asked what they considered to be the three most important values to them personally.

Table 1:1 Values of European Fieldwork Report (three most important values to you personally)

\begin{tabular}{|l|c|c|}
\hline Values & $\mathbf{2 0 1 2}$ & $\mathbf{2 0 1 0}$ \\
\hline Human Rights & $42 \%$ & $47 \%$ \\
\hline Respect for Human Life & $43 \%$ & $41 \%$ \\
\hline Peace & $40 \%$ & $44 \%$ \\
\hline Democracy & $28 \%$ & $29 \%$ \\
\hline Individual Freedom & $23 \%$ & $23 \%$ \\
\hline Equality & $20 \%$ & $19 \%$ \\
\hline Solidarity, support for others & $15 \%$ & $15 \%$ \\
\hline Tolerance & $15 \%$ & $15 \%$ \\
\hline Self Fulfillment & $11 \%$ & $10 \%$ \\
\hline Respect for Other Cultures & $9 \%$ & $8 \%$ \\
\hline Religion & $5 \%$ & $6 \%$ \\
\hline
\end{tabular}

Source: Eurobarometer 772012.

Europeans first mention human rights (42\%) and respect for human life (43\%). These two values were followed by peace (40\%). Democracy stands fourth in the ranking of values that matter most to Europeans (28\%), followed by individual freedom (23\%). These are followed by equality (20\%), solidarity (15\%), tolerance (15\%), ahead of self-fulfillment (11\%), respect for other cultures (9\%), and religion (5\%) [Eurobarometer 77 2012: 9]. We can see that there is a slight drop in adherence to all these values when we compare 2010 to 2012.

The data from the above table shows that Europeans appear to hold the value of religion very low in their esteem because only 5-6\% put it at the top. Even though that may be partly 
true, we can try to explain this by referring to the privatisation of religion which shows that religion is considered more important than it appears to be. The next table confirms it.

Table 1:2 Acceptance of faith in God in some old EU Member States (Which of these comes closest to your beliefs?)

\begin{tabular}{|l|c|c|c|c|}
\hline & $\begin{array}{c}\text { I believe in } \\
\text { God (\%) }\end{array}$ & $\begin{array}{c}\text { I believe in } \\
\text { some sort of } \\
\text { spirit (\%) }\end{array}$ & $\begin{array}{c}\text { I don't believe } \\
\mathbf{( \% )}\end{array}$ & $\begin{array}{c}\text { Don't know } \\
\mathbf{( \% )}\end{array}$ \\
\hline EU 25 & 52 & 27 & 18 & 3 \\
\hline Italy & 74 & 16 & 6 & 3 \\
\hline Spain & 59 & 21 & 18 & 2 \\
\hline Germany & 47 & 25 & 25 & 3 \\
\hline UK & 38 & 40 & 20 & 2 \\
\hline France & 34 & 27 & 33 & 5 \\
\hline
\end{tabular}

Source: Eurobarometer 2252005.

Table 1:2 shows the responses to the question regarding faith in God in some of the member countries of the EU (the oldest members). Just over half of the people (52\%) who answered the question stated "I believe in God" while $27 \%$ of people chose the answer: "I believe in some sort of spirit" and only $18 \%$ chose the answer "I don't believe". In the first 5 members of the EU the highest percentage of people who declared faith in God was in Italy with 74\%, but in countries with the highest number of immigrants like Germany only $47 \%$ declared they had faith in God, in the UK the number was even lower at 38\% and in France at 34\%. In Table 1:3 depicting the new EU member states, Malta scores high with 95\% believing in God, and the lowest is Estonia with only $16 \%$. This means that Europe is very diverse at its level of belief.

Table 1:3 Acceptance of faith in God in some newer EU Member States (Which of these comes closest to your beliefs?)

\begin{tabular}{|l|c|c|c|c|}
\hline & $\begin{array}{c}\text { I believe } \\
\text { in God (\%) }\end{array}$ & $\begin{array}{c}\text { I believe in some } \\
\text { sort of spirit (\%) }\end{array}$ & $\begin{array}{c}\text { I don't believe } \\
\text { (\%) }\end{array}$ & $\begin{array}{c}\text { Don't know } \\
\text { (\%) }\end{array}$ \\
\hline Malta & 95 & 3 & 2 & \\
\hline Cyprus & 90 & 7 & 2 & 3 \\
\hline Romania & 90 & 8 & 1 & 1 \\
\hline Poland & 80 & 15 & 2 & 3 \\
\hline Czech Rep. & 19 & 50 & 30 & 1 \\
\hline Estonia & 16 & 54 & 26 & 4 \\
\hline
\end{tabular}

Source: Eurobarometer 2252005. 
Besides the question regarding faith, the EU population was examined regarding their opinion about the legislation of homosexual marriages (Table 1:4). The highest percentage of people who said that homosexual marriage should be allowed throughout the EU was in the Netherlands (82\%), Sweden had 71\%, and the lowest was in Romania at $11 \%$, Poland had $17 \%$ and the average in the EU was $44 \%$.

Table 1:4 Homosexual marriage should be allowed throughout the EU

\begin{tabular}{|l|c|l|c|l|c|l|c|}
\hline Country & $\mathbf{\%}$ & Country & $\mathbf{\%}$ & Country & $\mathbf{\%}$ & Country & $\mathbf{\%}$ \\
\hline The Netherlands & 82 & Czech Rep. & 52 & Slovenia & 31 & Poland & 17 \\
\hline Sweden & 71 & Austria & 49 & Portugal & 29 & Greece & 15 \\
\hline Denmark & 69 & France & 48 & Estonia & 21 & Bulgaria & 15 \\
\hline Belgium & 62 & United Kingdom & 46 & Slovakia & 19 & Cyprus & 14 \\
\hline Luxemburg & 58 & Finland & 45 & Hungary & 18 & Latvia & 12 \\
\hline Spain & 56 & Ireland & 41 & Malta & 18 & Rumania & 11 \\
\hline Germany & 52 & Italy & 31 & Lithuania & 17 & $\begin{array}{l}\text { European } \\
\text { Union }\end{array}$ & 44 \\
\hline
\end{tabular}

Source: Eurobarometer 662006.

Table 1:5 Adoption of children should be authorised for homosexual couples throughout Europe

\begin{tabular}{|l|c|l|c|l|c|l|c|}
\hline Country & $\mathbf{\%}$ & Country & $\mathbf{\%}$ & Country & $\mathbf{\%}$ & Country & $\mathbf{\%}$ \\
\hline The Netherlands & 69 & Czech Rep. & 24 & Slovenia & 17 & Poland & 7 \\
\hline Sweden & 51 & Austria & 44 & Portugal & 19 & Greece & 11 \\
\hline Denmark & 44 & France & 35 & Estonia & 14 & Bulgaria & 12 \\
\hline Belgium & 43 & United Kingdom & 33 & Slovakia & 12 & Cyprus & 10 \\
\hline Luxemburg & 39 & Finland & 24 & Hungary & 13 & Latvia & 8 \\
\hline Spain & 43 & Ireland & 30 & Malta & 7 & Rumania & 8 \\
\hline Germany & 42 & Italy & 24 & Lithuania & 12 & $\begin{array}{l}\text { European } \\
\text { Union }\end{array}$ & 32 \\
\hline
\end{tabular}

Source: Eurobarometer 662006.

The survey [Eurobarometer 225 2005] also shows that openness towards homosexuality tends to be quite limited. On average, only $32 \%$ of Europeans feel that homosexual couples should be allowed to adopt children throughout Europe (Table 1:5). In fact, in 14 of the 25 Member States, less than a quarter of the public accepts adoption by homosexual couples. Public opinion tends to be somewhat more tolerant as regards homosexual marriages, 44\% of EU citizens agree that such marriages should be allowed throughout Europe. It should 
be noted that some Member States distinguish themselves from the average result by very high acceptance levels: the Netherlands tops the list with $82 \%$ of respondents in favour of homosexual marriages and $69 \%$ supporting the idea of adoption by homosexual couples. Opposition is strongest in countries like Greece and Latvia, Poland (76\% and 89\%). One has to remember that homosexual marriages (or a similar union between two persons of the same gender) are allowed in the Netherlands, Belgium, Spain, Sweden and in the UK [Eurobarometer 66 2006: 41-42].

\subsection{The Data from the England \& Wales Census 2011 - decline of religion in the UK}

Data from England \& Wales Census 2011 revealed the stunning decline of religion in the UK - with the number of Christians dropping by more than 4 million. Just 59.3 per cent of people in England and Wales now describe themselves as followers of Christianity (33.2 million). The proportion of Muslims has risen from 3.0 per cent to 4.8 per cent (2.7 million) since 2001. No religious affiliation rose from 14.8 per cent in 2001 to 25.1 per cent (14.1 million) in 2011. The religious question was the only voluntary question on the 2011 census and 7.2 per cent of people did not answer the question.

Despite the falling numbers Christianity remained the largest religion in England and Wales in 2011. Muslims are the next biggest religious group and have grown in the last decade. Meanwhile the number of the population who reported they had no religion has now reached a quarter. In January 2015 the "Daily Mail", a British newspaper, blamed aggressive anti-religious campaigning by high-profile atheists, for the situation that a quarter of Britons now say they have no faith [MailOnline 2015].

In 2011, London was the most diverse region with the highest proportion of people identifying themselves as Muslim, Buddhist, Hindu and Jewish. The North East and North West had the highest proportion of Christians and Wales had the highest proportion of people reporting no religion. Knowsley in Liverpool was the local authority with the highest proportion of people reporting to be Christians at 80.9 per cent and Tower Hamlets had the highest proportion of Muslims at 34.5 per cent (over 7 times the England and Wales figure). Norwich had the highest proportion of the population reporting no religion at 42.5 per cent [Office for National Statistics 2012].

One of the signs of changing values in the UK from religious to secular values was a longrunning court case in the UK. Seven years ago a child was born with foetal alcohol syndrome resulting in a range of disabilities. The child's mother was accused of poisoning her foetus by drinking an excessive amount of alcohol while pregnant. Apparently she had drunk 
eight cans of strong lager and half a bottle of vodka a day. The appeal judges ruled in early December 2014 that she had not committed a criminal offence. Ann Furedi, head of the British Pregnancy Advisory Service commented on the decision saying: "This is an extremely important ruling for women everywhere. The UK's highest courts have recognized that women must be able to make their own decisions about their pregnancies" [Acbr 2014].

Not everyone in the West agrees with abortion or the right of women to choose, over the right of their unborn child. Very often demonstrations have occurred across the world in support of Pro-Life. In the case above, the Society for the Protection of Unborn Children (SPUC) reacted strongly against the Court of Appeal's judgment. Paul Tully, SPUC's general secretary, said: "This cruel judgment not only leaves disabled children without just recompense, it flies in the face of common knowledge about when life begins and - it is anti-rational" [SPUC 2014].

\section{MUSLIM BELIEFS AND MORAL ATITUDE IN THE WORLD}

In the second part we look at Muslim beliefs and attitudes to family and protection of life. Firstly, let us look at areas in the world with a strong Muslim presence (Table 2:1). About 94\% of Muslim people in South East Asia believe it is necessary to believe in God to be a moral person and 91\% of Muslims in the Middle East and North Africa agree with them. However not so far away in Sub Sahara Africa only 70\% agree and the number is even lower in South East Europe (61\%).

Table 2:1 Is it Necessary to believe in God to be a moral person?

\begin{tabular}{|c|c|c|c|c|c|}
\hline $\begin{array}{c}\text { South East } \\
\text { Asia }\end{array}$ & $\begin{array}{c}\text { Middle } \\
\text { East, North } \\
\text { Africa }\end{array}$ & South Asia & $\begin{array}{c}\text { Sub Saharan } \\
\text { Africa }\end{array}$ & Central Asia & $\begin{array}{c}\text { South East } \\
\text { Europe }\end{array}$ \\
\hline $94 \%$ & $91 \%$ & $87 \%$ & $70 \%$ & $69 \%$ & $61 \%$ \\
\hline
\end{tabular}

Source: Pew Research Center 2014.

Table 2:2 Is abortion moral? (\% of Muslims)

\begin{tabular}{|l|c|c|c|}
\hline & $\begin{array}{c}\text { Morally wrong } \\
(\%)\end{array}$ & $\begin{array}{c}\text { Morally } \\
\text { acceptable (\%) }\end{array}$ & Don't know (\%) \\
\hline Thailand & 99 & & 1 \\
\hline Pakistan & 82 & & 18 \\
\hline Bangladesh & 64 & 18 & 18 \\
\hline Afghanistan & 55 & 4 & 41 \\
\hline Azerbijan & 23 & 3 & 74 \\
\hline
\end{tabular}

Source: Pew Research Center 2014. 
It is clear that even Muslims perceptions of moral issues vary. In Table 2:2 that looks at the question: Is abortion moral?, we can compare a number of countries in a region. Nearly all Muslims in Thailand (99\%) declared abortion to be morally wrong whereas in Azerbijan only $23 \%$ agreed it was morally wrong, with $3 \%$ saying it was acceptable and a huge $74 \%$ undecided. Bangladesh had $64 \%$ agreeing it was morally wrong but $18 \%$ saying it was morally acceptable and $18 \%$ undecided.

Table 2:3 Is sex outside of marriage moral? (\% Muslims)

\begin{tabular}{|l|c|c|c|}
\hline & $\begin{array}{c}\text { Morally wrong } \\
(\%)\end{array}$ & $\begin{array}{c}\text { Morally } \\
\text { acceptable (\%) }\end{array}$ & Don't know (\%) \\
\hline Thailand & 99 & & 1 \\
\hline Jordan & 96 & 1 & 3 \\
\hline Albania & 58 & 25 & 17 \\
\hline Bosnia- Herzegovina & 53 & 26 & 21 \\
\hline
\end{tabular}

Source: Pew Research Center 2014.

In Table 2:3 we see that the majority of Muslims in Thailand (99\%) and Jordan (96\%) believe sex outside of marriage to be morally wrong. However in Albania only $58 \%$ and in Bosnia-Herzegovina (53\%) believe it to be wrong, while 25\% of Albanians and even more Muslims from Bosnia-Herzegovina believe it is morally acceptable with almost a fifth of the people undecided.

Table 2:4 Is homosexual behaviour moral? (\% Muslims)

\begin{tabular}{|l|c|c|c|}
\hline & $\begin{array}{c}\text { Morally wrong } \\
(\%)\end{array}$ & $\begin{array}{c}\text { Morally } \\
\text { acceptable (\%) }\end{array}$ & Don't know (\%) \\
\hline Thailand & 99 & & 1 \\
\hline Indonesia & 95 & 1 & 4 \\
\hline Tajikstan & 82 & & 18 \\
\hline Kyrgystan & 76 & 3 & 21 \\
\hline
\end{tabular}

Source: Pew Research Center 2014.

Comparing countries in Asia (Table 2:4) we again see that almost 100\% of Muslims in Thailand believe that homosexual behaviour is immoral. Indonesian Muslims feel almost as strongly (95\%) although 4\% are no longer sure whether homosexual behaviour is immoral. Kyrgystan has many more people questioning if it is immoral or not with $21 \%$ declaring they don't know. 


\section{CO-OPERATION OF CHRISTIANS AND MUSLIMS ON THE BASIS OF THE UN, STATES AND NGO'S IN THE AREA OF PROTECTION OF HUMAN LIFE AND FAMILY LEGISLATION}

\subsection{Description of Muslim-Christian Co-operation}

Historically as 'People of the Book', in spite of times of war and intolerance, Muslims, Christians and Jews have been co-operating on many levels, in particular against moral evil [Center for Islamic Studies]. Now approximately 54\% of the world's population are either Christian or Muslim and naturally their relationship has considerable significance for the well being of all humanity.

In the second part of the 20th century Christians and Muslims co-operated closely in the area of legislation for the protection of human life and family. In 1964 during the Vatican II Council Pope Paul VI established a Secretariat for Non-Christian Religions (later renamed Pontifical Council for Interreligious Dialogue). Then in the years 1980-1990's there were a number of programs involving Muslim-Christian dialogue: The Muslim World League, the World Muslim Congress, and the Middle East Council of Churches [Oxford Islamic Studies on Line].

In the UK, the Society for the Protection of Unborn Children (SPUC) has Muslim support. In recent years SPUC Muslims have written a letter requesting British Muslims to attend a mass lobby of Parliament against euthanasia [SPUC]. In April 2012 Roman Catholic Leaders were urged by the Vatican to form a united front with Muslim to oppose gay marriage [Bingham 2012]. However we should note that many Muslim MPs voted in support of same sex marriages. There are over 35 organisations that encourage inter Faith co-operation and understanding in the UK: Christian Muslim Forum [Christian Muslim Forum], Faiths Forum for London, Interfaith Action, Interfaith Alliance UK to name but a few.

\subsection{UN Conferences in the second part of the 20th century - examples of Christian-}

\section{Muslim co-operation}

In the second part of the twentieth century there were several large and important international conferences, involving co-operation between the two Faiths, on population, development, poverty and women's rights, organized by the United Nations. Although they related to a variety of issues, their program documents show common threads associated with overpopulation, birth control, abortion, differing forms of families, and women's rights [Balicki, Frątczak, Nam 2007: ${ }^{1}$

1 They included Conference on Population in Bucharest 1974, Population Conference in Mexico 1974, International Conference on Population and Development in Cairo 1994, The Environment 
The preparation for the conferences and the exchanges during them often revealed some serious political and ideological differences that hindered agreement. Political difficulties resulted from the suspicion that rich countries with low, zero or negative natural increase were afraid to change the proportion of people in the world as it might be detrimental to their well being and prosperity. Ideological difficulties were related to an attempt to rebuild the traditional moral principles, the concept of the family and the place and role of women in society rights [Balicki, Frątczak, Nam 2007: 317-380].

During these Conferences a delegation from the Holy See (Vatican) cooperated with Muslim Countries trying to prevent anything that would be a danger to family, dignity of women and traditional religious values from being put into the Program of Action (a document prepared during the Conferences).

The Holy See had reservations regarding the terms 'sexual health' and 'sexual rights', and 'reproductive health' and 'reproductive rights'. The Holy See considered these terms as applying to a holistic concept of health, which embrace, each in their own way, the person in the entirety of his or her personality, mind and body, and which foster the achievement of personal maturity in sexuality and in the mutual love and decision-making that characterize the conjugal relationship in accordance with moral norms [Programme of Action 1994].

\section{The representative of the Islamic Republic of Iran submitted the following written statement about the Program of action Statement:}

"Although it has some positive elements, does not take into account the role of religion and religious systems in the mobilization of development capabilities. (...) It suffices for us to know that Islam, for example, makes it the duty of every Muslim to satisfy the essential needs of the community and also imposes the duty of showing gratitude for benefits by utilizing them in the best possible way, as well as the duties of justice and balance. (...) There are some expressions that could be interpreted as applying to sexual relations outside the framework of marriage, and this is totally unacceptable (...) The use of the expression «individuals and couples» and the contents of principle 8 demonstrate this point. We have reservations regarding all such references in the document. We believe that sexual education for adolescents can only be productive if the

and Development Conference Rio de Janeiro 1992, the World Summit for Social Development in Copenhagen in 1995; The United Nations Fourth World Conference on Women Beijing 1995, Human Settlements in Istanbul 1996 and the World Food Summit Rome 1996. 
material is appropriate and if such education is provided by the parents and aimed at preventing moral deviation and physiological diseases" [Programme of Action 1994].

During the above mentioned UN Conferences (at least Cairo, Copenhagen, Beijing, Istanbul and Rome) there were non-official regular daily meetings of pro-life and pro-family NGOS's with representatives of Muslims non-governmental organizations and representatives of the Holy See delegation to prepare a common position for the next day in order to lobby the delegates from the UN states more effectively. Stanly Johnson described this co-operation on a more official level [Johnson 1995].

In the 21st century there are no longer big UN conferences every ten years instead commissions meet every year. The UN Assembly decided that together with the Council and the Commission they should constitute an intergovernmental mechanism that would play the primary role in the follow-up to the implementation of the Program of Action of the International Conference on Population and Development in Cairo 1994. In connection with this there is still a co-operation between Muslim World and the Holy See and Christians and Muslims at an official level and at the NGO's level.

\section{CO-OPERATION OF CHRISTIANS AND MUSLIMS IN GREAT BRITAIN}

\subsection{Muslim population in EU}

Rich countries of the EU have always been a target of immigration. Migrants choice of their country of destination is usually connected with a colonial path. The main countries of destination for immigrants of Muslim countries are France, Germany, England, Italy and the Netherlands.

The Muslim population in France (2010) was $4.7 \mathrm{mln}$ that is $7.5 \%$ of the French population. In 2030 it could rise to $6.8 \mathrm{mln}$ which will constitute about $10.3 \%$ of the French population. In 2010 in Germany there were $4.1 \mathrm{mln}$. Muslims which constituted approximately $5 \%$ of the German population. According to the prognosis in 2030 it could reach $5.5 \mathrm{mln}, 7.1 \%$ of the whole population. In third place comes the UK with $2.8 \mathrm{mln}(2010)$ i.e. $4.6 \%$ and by $2030-5.5 \mathrm{mln}(8.2 \%)$. Italy had $1.5 \mathrm{mln}$ in 2010 (2.6\% of the Italian population) and by by 2030 there will be $3.2 \mathrm{mln}$ Muslims there $(5.4 \%$ of the whole population). In Spain it was $1 \mathrm{mln}(2.3 \%)$ and by 2030 it will be $1.8 \mathrm{mln}$ (3.7\% of the whole population). The Netherlands had only $0.9 \mathrm{mln}$ in 2010 , but this amounted to $5.5 \%$ of the population and by 2030 there will probably $1.3 \mathrm{mln}$ (7.8\%) Muslims there. [Pew Research Center 2011: 124]. 
Table 4:1 Muslim population in the selected EU countries

\begin{tabular}{|l|c|c|c|c|}
\hline Countries & $\begin{array}{c}\text { Muslim } \\
\text { population } \\
2010 \mathrm{mln}\end{array}$ & $\begin{array}{c}\% \\
2010\end{array}$ & $\begin{array}{c}\text { Muslim } \\
\text { population } \\
2030 \mathrm{mln}\end{array}$ & $\begin{array}{c}\% \\
2030\end{array}$ \\
\hline France & 4.7 & 7.5 & 6.8 & 10.3 \\
\hline Germany & 4.1 & 5.0 & 5.5 & 7.1 \\
\hline Italy & 1.5 & 2.6 & 3.2 & 5.4 \\
\hline Netherlands & 0.9 & 5.5 & 1.3 & 7.8 \\
\hline Spain & 1.0 & 2.3 & 1.8 & 3.7 \\
\hline U K & 2.8 & 4.6 & 5.5 & 8.2 \\
\hline
\end{tabular}

Source: Pew Research Center 2011: 124.

\subsection{Moral Values of Immigrants from Muslim Countries in Great Britain}

In order to show the possible influence of Muslim immigrants values on the European society let's look at Great Britain. According to the research of Munira Mirza, Abi Senthilkumaran and Zein Ja'far [Mirza, Senthilkumaran, Ja'far 2007] immigrants from Muslim countries appear much more religious than the rest of the European society although for example as no research has been carried out regarding how often people pray it cannot be taken as a definitive answer. There are many people in Great Britain who do not attend church but pray. In Great Britain belief in God and prayer are considered to be a very private affair. It is difficult to make a direct comparison between European Muslims and Christians with respect to habits of religious observance [Klausen 2005: 139-140].

Table 4:1 How often do you pray? (\% Muslims)

\begin{tabular}{|c|c|c|c|c|}
\hline Never (\%) & $\begin{array}{c}\text { Occasionally } \\
(\%)\end{array}$ & $\begin{array}{c}\text { Once a week } \\
(\%)\end{array}$ & $\begin{array}{c}\mathbf{1 - 3} \text { times } \\
\text { a day (\%) }\end{array}$ & $\begin{array}{c}\mathbf{5} \text { times a day } \\
(\%)\end{array}$ \\
\hline 5 & 15 & 9 & 22 & 49 \\
\hline
\end{tabular}

Source: Mirza, Senthilkumaran, Ja'far 2007.

Muslims were asked how often they prayed (Table 4:1). Almost half of those asked said 5 times a day with only 5\% saying never. Muslims were asked if they agreed with the statement that 'My religion is the most important thing in my life (Table 4:2) Two thirds $(66 \%)$ of Muslims agreed with that statement with only $4 \%$ disagreeing strongly and $1 \%$ unsure. 
Table 4:2 My religion is the most important thing in my life. (\% Muslims)

\begin{tabular}{|c|c|c|c|c|}
\hline $\begin{array}{c}\text { Agree } \\
\text { Strongly (\%) }\end{array}$ & $\begin{array}{c}\text { Tend to agree } \\
\text { (\%) }\end{array}$ & $\begin{array}{c}\text { End to } \\
\text { disagree (\%) }\end{array}$ & $\begin{array}{c}\text { Disagree } \\
\text { strongly (\%) }\end{array}$ & $\begin{array}{c}\text { Don't know } \\
\text { (\%) }\end{array}$ \\
\hline 66 & 20 & 9 & 4 & 1 \\
\hline
\end{tabular}

Source: Mirza, Senthilkumaran, Ja'far.

In the research from Newham College declarations of moral values of young immigrants from Muslim countries regarding marriage and cohabitation showed a sign of departure from traditional religious values. The students in Newham College were asked their views on pre-marital gender relationships. Very few Muslims supported the idea of cohabitation. Of Muslims born in the UK 28.6\% of males supported it but only half that number of females $14.4 \%$ agreed. Muslims born outside the UK felt more strongly that it was not acceptable: $51.6 \%$ of males said 'definitely not' and a significantly higher percentage of females (76.6\%) agreed with them.

The difference between Christian and Muslim students was more obvious, with $43.9 \%$ of Christian students and 13,2\% of Muslim students saying it was acceptable acceptable ('Yes, definitely') in response to the question. Do you think it is okay for a man and woman to live together without marrying? However exactly the same percentage of Christians and Muslims chose the answer 'Maybe'. We see again a significant difference in the answer 'definitely not': 26.3\% Christians and 57\% Muslims (Table 4.3) [Balicki, Wells 2011: 76-77].

Table 4:3 Attitude of students towards co-habiting

\begin{tabular}{|l|l|c|c|c|c|}
\hline \multirow{2}{*}{ Religion } & $\begin{array}{c}\text { Yes. } \\
\text { Definitely }\end{array}$ & Maybe & $\begin{array}{c}\text { Definitely } \\
\text { Not }\end{array}$ & Total \\
\hline \multirow{3}{*}{ Christian } & Number & 25 & 17 & 15 & 57 \\
\cline { 2 - 6 } & $\%$ & 43.9 & 29.8 & 26.3 & 100 \\
\hline \multirow{3}{*}{ Muslim } & Number & 16 & 36 & 69 & 121 \\
\cline { 2 - 6 } & $\%$ & 13.2 & 29.8 & 57.0 & 100 \\
\hline \multirow{3}{*}{ Total } & Number & 41 & 53 & 84 & 178 \\
\cline { 2 - 6 } & $\%$ & 23.0 & 29.8 & 47.2 & 100 \\
\hline
\end{tabular}

Source: Balicki, Wells 2011: 209-210.

\subsection{Muslim - Christian co-operation in Great Britain - examples}

A good example of Muslim and Christians co-operation in the area of the sanctity of human life in the UK, is the pro-life organization, SPUC. In the statement, "Why Muslim sisters 
and brothers should join the pro-life campaign", a deep explanation regarding Islamic/ religious, humane, health/medical and social reasons are given. Muslims are requested to work with non-Muslims to protect and save lives [SPUC].

In order to give an example of Christian-Muslim co-operation in the area of moral values we can refer to the Muslim appeal letter to all British Muslims to attend a mass lobby of Parliament against euthanasia:

"Brothers and sisters Assalamu Alaykum. Mass lobby of Parliament Against Euthanasia! on 27 and 28 April/04 at House of Commons. This Bill if we do not stop it and oppose it, it will put the sick and elderly people and persons with disabilities at risk and will cause their slow and painful death from lack of food(starvation), and from lack of fluids(dehydration): Euthanasia by neglect!!!! The proposed Bill will forces doctors to WITHHOLD ordinary medical care from some patients when they are no longer able to speak for themselves!" [Pro-life Muslims 2004].

Another example of this co-operation came from the Pope's representative in Britain who urged Roman Catholic leaders to form a united front with their Muslim and Jewish counterparts to oppose gay marriage. In Scotland, the Council of Glasgow Imams have recently agreed on a joint resolution describing same-sex marriage as an "attack" on their faith and fundamental beliefs [Bingham 2012].

The purpose of presenting the above examples is to show that Christians and Muslims are already co-operating and supporting each other in their efforts to protect common values regarding family and sanctity of human life. Christians and Muslims together form the biggest religious community in the world. In 2010 it was $54 \%$ of the world population, in 2050 it will be more than $63 \%$. Even if these percentages refer to anyone who calls themselves Christian or Muslim and not to their personal beliefs and attitudes, that means that these religions could have a great influence on the moral values in the world. Muslim support in the area of religion and traditional morality will be very welcome by active Christians because there has been a quick process of secularization in Europe and the emergence of a very active group of well known people who openly declare atheism, for example Richard Dawkins (a well-known British biologist) and Douglas Murray (a British writer, journalist and commentator) who are often present their views on television and the Internet. 
Table 4:4 Christian - Muslim population 1910-2010-2050

\begin{tabular}{|l|c|c|c|}
\hline & World & Christians & Muslims \\
\hline Year & \multicolumn{3}{|c|}{ Billions } \\
\hline $\mathbf{1 9 1 0}$ & 1,758 & 0,611 & 0,221 \\
\hline $\mathbf{2 0 1 0}$ & 6,895 & $2,260(33 \%)$ & $1,553(21 \%)$ \\
\hline $\mathbf{2 0 5 0}$ & 9,306 & $3,327(35.7 \%)$ & $2,554(27.4 \%)$ \\
\hline
\end{tabular}

Source: Johnson, Grim 2013: 10, 116, 118.

\section{MAIN CONCLUSIONS}

In Europe the process of changes in society is quite advanced. It is usually defined as postmodernism and described by the decline of religiosity, the growth of individualism (eg. high approval of homosexual marriages and the adoption of children by homosexual couples), cohabitation, birth out of wedlock, divorce and moving away away from the traditional Judeo-Christian values.

This study points out that in Muslim countries religion and traditional values are still very important. Therefore, the aim of this article was to identify possible areas of co-operation between Christians and Muslims in the secular world and the basic conditions that must be met in this co-operation.

For many years a close co-operation has existed between Muslims and Christians in the defense of common values at an institutional level. They have struggled to prevent the adoption of UN documents that undermine family values, traditional sexual ethics, questioning the pressure exerted on the states to legalize abortion, or euthanasia in the case of terminal illness. This is undoubtedly a very important partnership, which indirectly may affect the value system of European society.

In the UK, the Society for the Protection of Unborn Children (SPUC) has Muslim support. In recent years SPUC Muslims wrote a letter requesting British Muslims to attend a mass lobby of Parliament against euthanasia and Roman Catholic Leaders were urged by the Vatican to form a united front with Muslim to oppose gay marriage. There are over 35 organisations that encourage interfaith co-operation and understanding in the UK.

A good example of Muslim and Christian co-operation in the area of sanctity of human life in UK, can be, above described, pro-life organization SPUC. Another example of this co-operation came from the Pope's representative in Britain who urged Roman Catholic 
leaders to form a united front with their Muslim and Jewish counterparts to oppose gay marriage. In Scotland, the Council of Glasgow Imams have recently agreed on joined a joint resolution describing same-sex marriage as an "attack" on their faith and fundamental beliefs. All those examples show that Christians and Muslims are already co-operating and supporting each other in their efforts to protect common values regarding family and sanctity of human life.

The strength of the help that immigrants from Muslim countries will give Christianity in Europe will depend on the integration of immigrants into the European society. It will depend on how well they are able to accept the positive values of European civilization (Human rights, freedom of conscience, equality of sexes), while not losing all that is valuable in their culture and civilization, values that Europe has lost to a certain extent (religiosity, traditional moral norms of sexual ethics, family ties, children's respect for parents).

Ks. Janusz Balicki - socjolog i politolog, dr hab., prof. UKSW, kierownik Katedry Polityk Publicznych Instytutu Politologii UKSW, członek m.in. Rządowej Rady Ludnościowej, Komitetu Badań nad Migracjami PAN oraz Working Group on Migration and Asylum (WGMA) - COMECE Bruksela. Zainteresowania badawcze: demografia społeczna, procesy migracyjne, polityka wielokulturowości. Autor m.in. Imigranci i uchodźcy w Unii Europejskiej. Humanizacja polityki imigracyjnej i azylowej (2012), The Pendulum Culture? Integration of Young Muslim Immigrants in East London (wraz z J. Wellsem, 2011) 


\section{Bibliography}

Acbr (2014), UK Court finds Drinking while Pregnant Not a Crime, http://mail.acbr.com/pipermail/ faslink_acbr.com/2014-December/023855.html.

Al Qaradawi Y. (2011), The Lawful and the Prohibited in Islam, Dar Al Taqua Ltd. London.

Balicki J., Frątczak E., Nam Ch. B. (2007), Przemiany ludnościowe. Fakty - interpretacje - opinie. Mechanizmy przemian ludnościowych. Globalna polityka ludnościowa, wyd. 2, Instytut Politologii UKSW, Wydawnictwo UKSW, Warszawa.

Balicki J. (2012), Imigranci i uchodźcy w Unii Europejskiej. Humanizacja polityki imigracyjnej i azylowej, Wydawnictwo UKSW, Warszawa.

Balicki J. (2010), Imigranci z krajów muzułmańskich w UE. Wyzwania dla polityki integracyjnej, Wydawnictwo UKSW, Warszawa.

Balicki J., Wells A. (2011), The Pendulum Culture? Integration of Young Muslim Immigrants in East London, Trafford, Bloomington, IN (USA).

Bingham J., Gay marriage: Pope representatives calls for Catholic alliance with Muslim and Jewish groups, „The Telegraph” (27.04.2012), http://www.telegraph.co.uk/news/religion/9232269/Gay-marriagePope-representatives-calls-for-Catholic-alliance-with-Muslim-and-Jewish-groups.html.

Center for Islamic Studies, Muslim's Alliance with Christians and Jews, A Voice from the Main Stream Islam, http://www.islamic-study.org/muslim_alliance_with_christians_and_jews.htm\#christians.

Christian Muslim Forum, http://www.christianmuslimforum.org.

Eurobarometer 225 (2005), Social values, Science and Technology, Fieldwork: January-February, Publication: June.

Eurobarometer 66. Public Opinion In The European Union First Results, Fieldwork: September-October 2006, Publication: December 2006.

Eurobarometer 77 (2012), The Values of Europeans Report Fieldwork: May 2012, the European Commission, Directorate-General for Communication. the European Standard Eurobarometer 77 / Spring 2012 - TNS Opinion \& Social. http://ec.europa.eu/public_opinion/archives/eb/eb77/ eb77_value_en.pdf.

Johnson Stanly (1995), The Politics of Population. The International Conference on Population and Development, Cairo 1994, Earthscan Publication, London.

Johnson Todd M., Grim Brian J. (2013), The World's Religions In Figures. An Introduction to International Religious Demography, Wiley-Blackwell, Oxford.

Klausen J. (2005), The Islamic Challenge. Political and Religion in Western Europe, Oxford University Press, New York.

Kotowska I. E. (ed.) (1999), Przemiany demograficzne w Polsce w latach 90. w świetle koncepcji drugiego przejścia demograficznego, SGH, Warszawa, s. 11-33.

MailOnline (2015), Saturday, Jan 24th.

Mirza Munira, Senthilkumaran Abi, Ja'far Zein (2007), Living Apart Together: British Muslims and the paradox of multiculturalism, Policy Exchange, London.

News, Foetal alcohol judgment is anti-rational, says pro-life group SPUC, www.spuc.org.uk.

Office for National Statistics (2012), 11 December 2012, http://www.ons.gov.uk/ons/dcp171776_290510. pdf.

Oxford Islamic Studies on Line, Muslim-Christian Dialogue, http://www.oxfordislamicstudies.com/ article/opr/t236/e0567.

Pew Research Center (2011), The Future of the Global Muslim Population, January.

Pew Research Center (2014), Worldwide, Many See Belief in God as Essential to Morality Richer Nations Are Exception, March 13. 
PolicyLiving apart together. British Muslim and paradox multiculturalism, Policy Exchange, Clutha House, 10 Storey's Gate, London SW1P 3AY, 2007.

Programme of Action (1994), Cairo, 5-13 September.

Pro-life Muslims (2004) Muslim appeal letter to the British Muslims for mass lobby of Parliament against Euthanasia, 27-28.04.2004, http://www.prolifemuslims.com/MUSLIM\%20APPEAL\%20 LETTER1.asp.

Social values, Science,Technology, Eurobarometr 2005.

SPUC (2014), Foetal alcohol judgment is anti-rational, says pro-life group SPUC, 4.12.2014, https://www.spuc.org.uk/news/press-releases/2014/december/foetal-alcohol-judgment -is-antirational-says-prolife-group-spuc.

SPUC, Why Muslim sisters and brothers should join the pro-life campaign, https://www.spuc.org.uk/ about/muslim-division/why.

van de Kaa Dirk J. (2002), The Idea of a Second Demographic Transition in Industrialized Countries, Paper presented at the Sixth Welfare Policy Seminar of the National Institute of Population and Social Security, Tokyo, Japan, 29.01.2002, http://www.ipss.go.jp/webj-ad/webjournal.files/ population/2003_4/kaa.pdf.

van de Kaa Dirk J. (2008), Demographic Transitions, Netherlands Interdisciplinary Demographic Institute (NIDI), The Hague, The Netherlands, March. 